\title{
Optimization of Bacteriocin Production from Lactobacillus gasseri NBL 18 through Response Surface Methodology
}

\author{
Neha Pandey* and Ravinder Kumar Malik
}

National Dairy Research Institute, Karnal, Haryana, India

*Corresponding author

\section{A B S T R A C T}

\section{Keywords}

Bacteriocins, Response surface methodology, Lactobacillus gasseri

Article Info

Accepted:

15 February 2019

Available Online:

10 March 2019
Response surface methodology (RSM) is a combination of statistical and mathematical techniques used to create the model and to analyze a response influenced by several factors. The present research was carried out to enhance bacteriocin production by the Lactic acid bacteria Lactobacillus gasseri NBL 18 isolated in our lab from infant fecal samples. The influence of physical parameters viz. temperature $\left(37-42^{\circ} \mathrm{C}\right), \mathrm{pH}(4.0-8.0)$, incubation time (6-24h) and inoculum level (1-3\%) on bacteriocin production was analyzed through RSM. Maximum bacteriocin production of $2.56 \times 10^{4} \mathrm{AU} / \mathrm{ml}$ was obtained at temperature $37^{\circ} \mathrm{C}, \mathrm{pH} 8.0$, inoculum size $3 \%$ and incubation time of $24 \mathrm{~h}$. Statistical analysis showed that all the four factors had significant effects on bacteriocin production. RSM proved to be a powerful tool in the optimization of bacteriocin production by $L$. gasseri NBL 18 .

\section{Introduction}

Bacteriocins are ribosomally synthesized antimicrobial peptides, which are produced by a wide variety of bacteria (De Vugst and Vandamme, 1994). They were originally defined as proteins characterized by lethal biosynthesis, predominantly intra-species killing activity and adsorption to specific receptors on the surface of bacteriocin sensitive cells (Joerger and Klaenhammer, 1990). Bacteriocins produced by Lactic Acid Bacteria (LAB) have presented a potential use in food industries as biopreservatives as they are able to inhibit the growth of a wide variety of bacteria, including many food spoilage bacteria and pathogens. In order to use a bacteriocin as a food preservative, either the bacteriocin producing strain is used as a starter culture or the bacteriocin in its pure form is used as a food additive. Direct application of bacteriocin for food preservation requires optimization of their production which is dependent on multiple strain-specific factors such as incubation time, temperature, $\mathrm{pH}$ and composition of the media (Zamhir et al., 2016). Therefore, it is necessary to conduct research to find out the optimum condition of bacteriocin production. Optimization culture conditions by conventional methods involve 
changing one independent variable while keeping constant all other variables. This method may lead to unreliable and wrong conclusions and also extremely time consuming and expensive (Oh et al., 1995).

Response surface methodology (RSM) is a collection of mathematical and statistical techniques that are useful for the modeling and analysis of problems in which a response of interest is influenced by several variables and the objective is to optimize this response (Montgomery, 1997). It is well suited to study the interaction of different factors on bacteriocin production (Cladera-Olivera et al., 2004; Leães et al., 2011; Kumar et al., 2012). In the present study the production of bacteriocin from $L$. gasseri NBL 18 was optimized through RSM for maximal bacteriocin production.

\section{Materials and Methods}

\section{Bacterial cultures}

The bacteriocin producing strain Lactobacillus gasseri NBL 18 was isolated from 0-6 months old infant fecal samples and identified by PCR analysis of its 16S-23SrRNA gene as described by Song et al., (2000). The nucleotide sequence has been deposited with NCBI data base under the accession number JQ809334.1. The indicator organism Enterococcus faecalis NCDC 114 was obtained from National Dairy Research Institute (NCDC), Karnal, Haryana, India.

\section{Bacteriocin Production}

MRS medium was inoculated with $1.0 \%$ of the inoculum (L. gasseri) and incubated at $37^{\circ} \mathrm{C}$ for 18-24hrs. The cell free culture supernatants (CFCS) was obtained by centrifuging at $12000 \mathrm{~g}$ for $10 \mathrm{~min}$ at $4^{\circ} \mathrm{C}$ and heating the supernatant to $90^{\circ} \mathrm{C}$ for 5-7 min to kill live cells and to inactivate the proteases. Further its $\mathrm{pH}$ was adjusted to 6.5 with $1 \mathrm{~N}$
$\mathrm{NaOH}$. This was used as crude bacteriocin.

\section{Antimicrobial activity assay}

The antimicrobial activity was evaluated by spot on lawn assay as described by Ulhmann et al., (1992). Antimicrobial activity was expressed in arbitrary units (AU/ml). Crude bacteriocin was two-fold serially diluted and one arbitrary activity unit (AU) was defined as the reciprocal of the highest dilution yielding a clear zone of inhibition on the indicator lawn (Ivanova et al., 2000).

\section{Response surface optimization of the cultivation conditions for maximal bacteriocin production by Lactobacillus gasseri NBL 18}

The central composite rotatable design (CCRD), one of the most important experimental designs used in process optimization studies was applied in this study with the objective to develop an empirical model of the process and to obtain a precise estimate of the optimum operating conditions for the factors involved. To describe the nature of the response surface in the optimum region, a four factor (five levels at each factor) second order central composite rotatable design (CCRD) was adopted. The independent factors viz: $\mathrm{pH}$ (A), Incubation temperature (B), Inoculation level (C) and Incubation Time (D) were considered for optimization of processing variables for bacteriocin production. The selected range for the variables was $4-8$ for $\mathrm{pH}, 37-42^{\circ} \mathrm{C}$ for incubation temperature, $1-3 \%$ inoculum level and 6-24 h of incubation period. For the four factors, the CCRD design constituted of 30 experiments as shown in Table 2. This design was made up of 24 factorial design, six replications of the center points and the eight axial design. The axial distance $\alpha$ was chosen to be 1.68 to make this design rotatable. A center point is a point in which all variables are set at their mid value. Six center 
experiments were included in factorial designs as repetition so as to minimize the risk of missing non- linear relationships in the middle of the intervals, and also for the determination of confidence intervals. The response function (Y) was bacteriocin produced (AU/ml). The response was related with the coded factors by a second -degree polynomial equation Eq. (1) using the least square method.

$\mathrm{Y}=\quad \mathrm{bo}+\mathrm{b} 1 \mathrm{~A}+\mathrm{b} 2 \mathrm{~B}+\mathrm{b} 3 \mathrm{C}+\mathrm{b} 4 \mathrm{D}+\mathrm{b} 11 \mathrm{~A} 2$ $+\mathrm{b} 22 \mathrm{~B} 2+\mathrm{b} 33 \mathrm{C} 2+\mathrm{b} 44 \mathrm{D} 2+\mathrm{b} 12 \mathrm{AB}+\mathrm{b} 13 \mathrm{AC}$ $+\mathrm{b} 14 \mathrm{AD}+\mathrm{b} 23 \mathrm{BC}+\mathrm{b} 24 \mathrm{BD}+\mathrm{b} 34 \mathrm{CD}+\varepsilon$

The coefficient of the polynomials were represented by bo (constant terms), b1, b2, b3 b4 (linear terms), b11, b22, b33, b44 (quaratic terms), b12, b23, b33 b14, b24 b34 (interactive terms) and $\varepsilon$ (random error). Thus the optimization of bacteriocin production was achieved using a central composite design and surface modelling method.

The results were analyzed by Design-Expert 8.0.7.1 package (StatEase, Inc., Minneapolis, MN, USA). Adequacy of the model was evaluated using $\mathrm{F}$ ratio, model was considered adequate when F-calculated was more than table-F. The analysis of variance (ANOVA) tables were generated and the effect of variables at linear, quadratic and interactive level on individual response was described using significance at 1 and 5\% levels of confidence. The magnitude and sign of coefficients in the model indicated the effects of variables on response. The magnitude of coefficient described the extent of dependency of variables on increasing or decreasing the response depending on positive or negative sign of coefficient terms. In the case of negative interaction, the level of one factor could be increased while decreasing the level of other variable. All negative coefficients of quadratic terms indicate maximum response at stationary point, all positive coefficients of quadratic terms indicate minimum response at origin of stationary point, whereas mixed sign of quadratic terms indicate mini-max response (middle point) at origin of stationary point (Table 1).

\section{Results and Discussion}

The design matrix representing different combinations of the four factors along with response (experiments were performed in triplicate) are delineated in Table 2. Regression coefficient and ANOVA of fitted quadratic model for bacteriocin production are shown in Table 3.

\section{Diagnostic check of the quadratic model}

The quadratic model for response Bacteriocin activity (AU/ml) was obtained through successive regression analysis. The dependence of the response with respect to levels of four factors $(\mathrm{pH}$, Temperature, Inoculum level and Incubation time) in the form of correlation is presented in Table 3. The model $\mathrm{F}$ values for all attributes were more than the Table $\mathrm{F}$ values at 5\% level of confidence and it indicated the significance of model terms. The lack of fit test, which measure the fitness of the model obtained, did not result in a significant $F$ value, indicating that the model is sufficiently accurate for predicting the bacteriocin production by $L$. gasseri NBL 18 from any combination of factor levels within the range evaluated.

\section{Effect of $\mathbf{p H}$, incubation time, inoculum level and incubation temperature on bacteriocin activity}

Bacteriocin activity after growth was highly significantly positively $(\mathrm{p}<0.01)$ affected by $\mathrm{pH}$ of the broth and inoculums level and negatively affected by incubation temperature and positively affected by incubation time, but statistically non-significant at linear level. At quadratic level, all parameter had positive effect, but all are non-significant. The interactive effect of $\mathrm{pH}^{*}$ incubation time had 
highly positive significant effect, $\mathrm{pH}$ and incubation temperature, and incubation temperature and incubation time had negative effect, but statistically non-significant. Other parameters were found to have no interactive effect. Multiple regression equation generated to predict the bacteriocin production as affected by different factors in terms of actual factors is as follows:

Bacteriocin activity $=+95.25000+10.42333$ $* \mathrm{pH}-6.84000 *$ Temperature $-2.33333 *$ Inoculum level $+1.44222 *$ Incubation time $0.32000 * \mathrm{pH} *$ Temperature $+3.24740 \mathrm{E}-$ $015^{*} \mathrm{pH} *$ Inoculum level $+0.22222^{*} \mathrm{pH}^{*}$ Incubation time $-2.66454 \mathrm{E}-015^{*}$ Temperature * Inoculum level $-0.071111 *$ Temperature * Incubation time - 2.59052E-016* Inoculum level * Incubation time $+0.062500 *$ $\mathrm{pH} 2+0.12000 *$ Temperature $2+0.65000 *$ Inoculum level $2+0.012963 *$ Incubation time 2 (Fig. 1).

Optimization of pH, incubation temperature, inoculation level and incubation time for maximum bacteriocin production

The optimization of levels of $\mathrm{pH}$, incubation temperature, inoculation level and incubation time was attempted using CCRD response surface design and conditions were set as presented in Table 4.
The optimum solution obtained as a result of numerical optimization was verified and the optimum level of $\mathrm{pH}$ (8.00), incubation temperature $\left(37^{\circ} \mathrm{C}\right)$, inoculation level $(3 \%)$ and incubation time (24h) were used for maximum bacteriocin production. The actual values of the optimization were compared with the predicted values given by the software using t-test as shown in Table 5. The t-test indicated that there were no significant differences between the predicted and the observed values of bacteriocin produced. This indicated that the model was significant and fitted to the date perfectly, so the bacteriocin produced was maximum from possible combinations of variables.

Environmental conditions such as $\mathrm{pH}$, inoculum level, incubation time and temperature not only affect the growth and biomass production of the culture but also determine the bacteriocin production in the medium. Moreover, these environmental conditions may interfere with bacteriocin stability (Leroy et al., 2005). Our experimental results are in agreement with the earlier reports of several researchers. Maximum production of bacteriocin from NBL 18 occurred at high cell densities (3\% inoculum level), which is supported by the reports for bacteriocins produced by other LAB (Van-Laack et al., 1992; Keppler et al., 1994).

Table.1 Coded and actual values of variables in RSM experiment

\begin{tabular}{|c|c|c|c|c|c|c|c|c|}
\hline \multirow[t]{2}{*}{ Level } & \multicolumn{4}{|c|}{ Coded } & \multicolumn{4}{|c|}{ Actual } \\
\hline & $\begin{array}{c}\text { Factor } \\
1\end{array}$ & $\begin{array}{c}\text { Factor } \\
2\end{array}$ & $\begin{array}{c}\text { Factor } \\
3\end{array}$ & $\begin{array}{c}\text { Factor } \\
4\end{array}$ & pH & $\begin{array}{l}\text { Incubation } \\
\text { temperature }\end{array}$ & $\begin{array}{c}\text { Inoculum } \\
\text { level }\end{array}$ & $\begin{array}{c}\text { Incubation } \\
\text { time }\end{array}$ \\
\hline-2.0 & -2.0 & -2.0 & -2.0 & -2.0 & 2 & 34.5 & 0 & -3 \\
\hline-1.0 & -1.0 & -1.0 & -1.0 & -1.0 & 4 & 37 & 1 & 6 \\
\hline $\mathbf{0}$ & 0 & 0 & 0 & 0 & 6 & 39.5 & 2 & 15 \\
\hline+1.0 & +1.0 & +1.0 & +1.0 & +1.0 & 8 & 42 & 3 & 24 \\
\hline+2.0 & +2.0 & +2.0 & +2.0 & +2.0 & 10 & 44.5 & 4 & 33 \\
\hline
\end{tabular}


Table. 2 Bacteriocin activity of the culture NBL 18 cultivated with different levels of $\mathrm{pH}$, Temperature, Inoculum level and Incubation time

\begin{tabular}{|c|c|c|c|c|c|}
\hline \multirow[t]{3}{*}{ S.N. } & \multicolumn{4}{|c|}{ Factors } & \multirow[b]{2}{*}{ Bacteriocin activity } \\
\hline & pH & Temperature & $\begin{array}{c}\text { Inoculum } \\
\text { level }\end{array}$ & Time & \\
\hline & (A) & (B) & (C) & (D) & $\left(\mathrm{X} 10^{4} \mathrm{AU} / \mathrm{ml}\right)$ \\
\hline 1 & 4.00 & 37.00 & 3.00 & 24.00 & $\mathbf{0}$ \\
\hline 2 & 8.00 & 42.00 & 1.00 & 24.00 & 1.28 \\
\hline 3 & 4.00 & 42.00 & 3.00 & 6.00 & $\mathbf{0}$ \\
\hline 4 & 6.00 & 39.50 & 2.00 & 15.00 & 0.16 \\
\hline 5 & 8.00 & 42.00 & 3.00 & 24.00 & 1.28 \\
\hline 6 & 4.00 & 37.00 & 3.00 & 6.00 & $\mathbf{0}$ \\
\hline 7 & 2.00 & 39.50 & 2.00 & 15.00 & $\mathbf{0}$ \\
\hline 8 & 4.00 & 42.00 & 3.00 & 24.00 & $\mathbf{0}$ \\
\hline 9 & 8.00 & 37.00 & 3.00 & 6.00 & 0.32 \\
\hline 10 & 6.00 & 39.50 & 4.00 & 15.00 & 0.32 \\
\hline 11 & 4.00 & 42.00 & 1.00 & 6.00 & $\mathbf{0}$ \\
\hline 12 & 6.00 & 39.50 & 2.00 & 15.00 & 0.16 \\
\hline 13 & 6.00 & 34.50 & 2.00 & 15.00 & 0.08 \\
\hline 14 & 6.00 & 39.50 & 2.00 & 15.00 & 0.16 \\
\hline 15 & 4.00 & 42.00 & 1.00 & 24.00 & 0 \\
\hline 16 & 4.00 & 37.00 & 1.00 & 24.00 & 0 \\
\hline 17 & 4.00 & 37.00 & 1.00 & 6.00 & 0 \\
\hline 18 & 8.00 & 42.00 & 1.00 & 6.00 & 0.32 \\
\hline 19 & 6.00 & 39.50 & 2.00 & -3.00 & 0 \\
\hline 20 & 8.00 & 37.00 & 1.00 & 24.00 & 2.56 \\
\hline 21 & 8.00 & 37.00 & 3.00 & 24.00 & 2.56 \\
\hline 22 & 8.00 & 42.00 & 3.00 & 6.00 & 0.32 \\
\hline 23 & 6.00 & 44.50 & 2.00 & 15.00 & 0.32 \\
\hline 24 & 6.00 & 39.50 & 2.00 & 33.00 & 0.64 \\
\hline 25 & 6.00 & 39.50 & 2.00 & 15.00 & 0.16 \\
\hline 26 & 6.00 & 39.50 & 2.00 & 15.00 & 0.16 \\
\hline 27 & 6.00 & 39.50 & 2.00 & 15.00 & 0.16 \\
\hline 28 & 6.00 & 39.50 & 0.00 & 15.00 & 0 \\
\hline 29 & 8.00 & 37.00 & 1.00 & 6.00 & 0.32 \\
\hline 30 & 10.00 & 39.50 & 2.00 & 15.00 & 0 \\
\hline
\end{tabular}


Table.3 Regression coefficients and ANOVA of fitted quadratic model for maximum bacteriocin production

\begin{tabular}{|c|c|}
\hline Partial coefficients & $\begin{array}{c}\text { Bacteriocin } \\
\text { activity }\end{array}$ \\
\hline Intercept & 1.60 \\
\hline A-pH & $3.73^{* *}$ \\
\hline $\begin{array}{l}\text { B-Incubation } \\
\text { temperature }\end{array}$ & -0.87 \\
\hline C-Inoculation level & $0.27^{* *}$ \\
\hline D- Incubation time & 3.20 \\
\hline$A^{2}$ & 0.25 \\
\hline $\mathrm{B}^{2}$ & 0.75 \\
\hline$C^{2}$ & 0.65 \\
\hline$D^{2}$ & 1.05 \\
\hline AB & -1.60 \\
\hline $\mathrm{AC}$ & 0.00 \\
\hline AD & $4.00^{* *}$ \\
\hline BC & 0.00 \\
\hline BD & -1.60 \\
\hline CD & 0.00 \\
\hline Model F value & $3.02^{*}$ \\
\hline $\mathbf{R}^{2}$ & 0.74 \\
\hline APV & 7.16 \\
\hline Lack of fit & NS \\
\hline
\end{tabular}

**Significant at $1 \%$ level $(\mathrm{P}<0.01)$

$*$ Significant at $5 \%$ level $(\mathrm{P}<0.05)$

Table.4 Conditions during optimization of bacteriocin production in CCRD

\begin{tabular}{|l|l|c|c|}
\hline Name & Goal & Low limit & Upper limit \\
\hline pH & In range & 4 & $\mathbf{8}$ \\
\hline $\begin{array}{l}\text { Incubation } \\
\text { temperature }\end{array}$ & In range & 37 & $\mathbf{4 2}$ \\
\hline Inoculation level & In range & 1 & $\mathbf{3}$ \\
\hline Incubation time & In range & 6 & $\mathbf{2 4}$ \\
\hline Bacteriocin activity & Maximize & $\mathbf{0}$ & $\mathbf{2 5 . 6}$ \\
\hline
\end{tabular}

Table.5 Optimized values as compared to predicted values

\begin{tabular}{|l|l|l|l|}
\hline Responses & Predicted score $^{*}$ & Observed score $^{\Theta}$ & t-value $^{\#}$ \\
\hline Bacteriocin production & 19.56 & $\mathbf{2 1 . 3 3}$ & $\mathbf{0 . 4 1}^{\mathrm{NS}}$ \\
\hline
\end{tabular}

*predicted values of Design Expert 8.0.7.1 package

${ }^{\circledR}$ actual values (mean of three trials); ${ }^{\#} \mathrm{p}<0.05$; ${ }^{\mathrm{NS}}$ nonsignificant 
Fig.1 Response surface curves for bacteriocin activity as influenced by the level of $\mathrm{pH}$, incubation temperature, inoculum level and incubation time

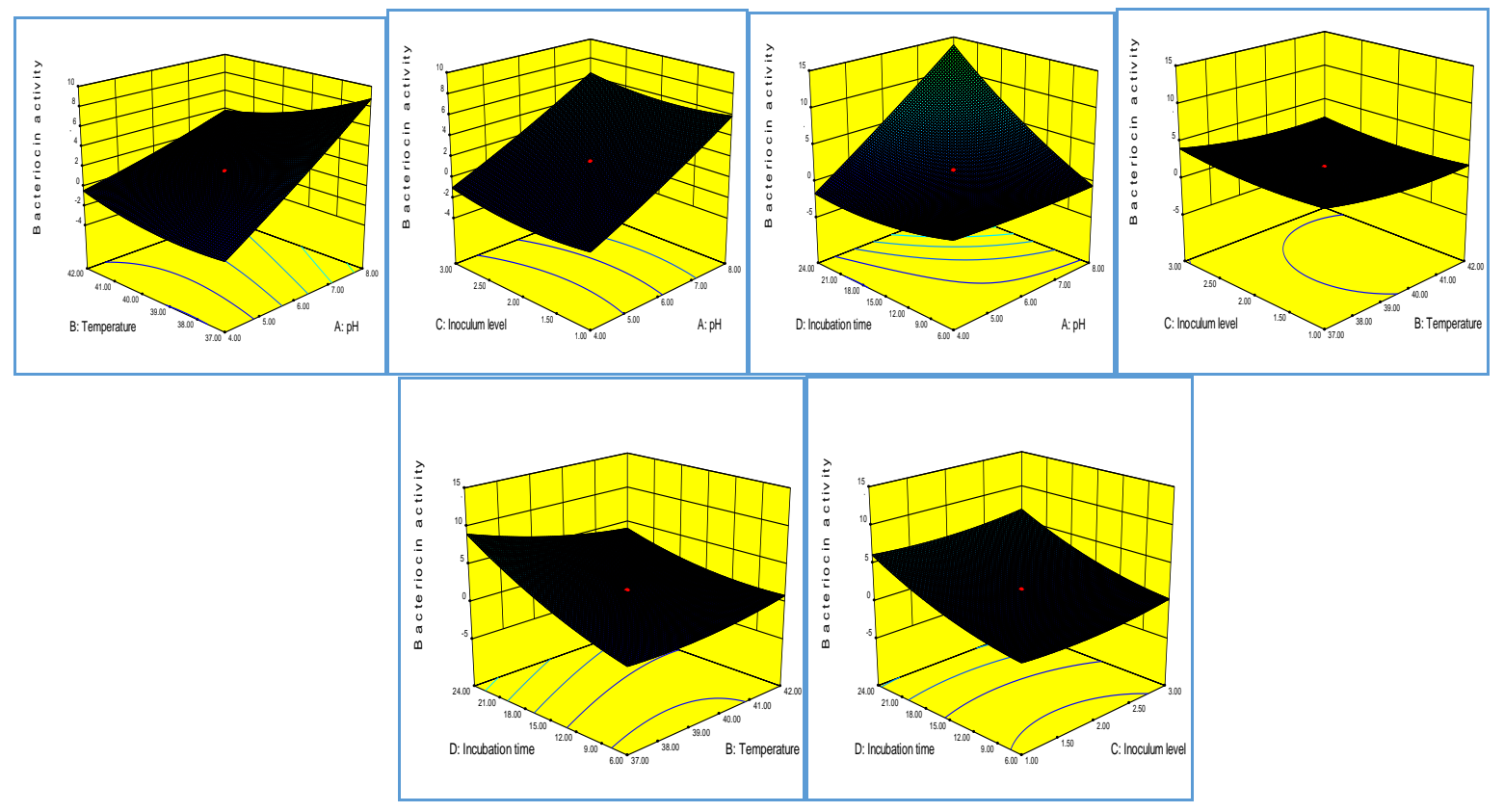

Various workers have reported that growth and bacteriocin production by a strain occurs at optimum levels in the neutral and slightly alkaline $\mathrm{pH}$ range (De Vugst and Vandamme, 1994; Franz et al., 1996; Kang and Lee, 2005). This is in support to our finding where a maximal bacteriocin production was obtained at a $\mathrm{pH}$ of 8.00 . The decrease in bacteriocin production at very low $\mathrm{pH}$ values in most of the cases has been attributed to the reduced cell mass.

Although the bacteriocin production is detected over a wide range of temperature, the production is maximum at the optimum temperature of growth of the producer strain and a relatively longer incubation times are needed to achieve the highest bacteriocin titres at low temperatures (Biswas et al., 1991; Schved et al., 1993; Todorov and Dicks, 2004). Similar results are obtained in our study with a maximal bacteriocin production at $37^{\circ} \mathrm{C}$ (optimum growth temperature for lactobacilli) for $24 \mathrm{~h}$. Some workers have also reported contradictory results where they found that the optimum temperature for the production of bacteriocins by a strain was lower than that of growth (Mataragas et al., 2003). RSM results indicated all the four factors studied have significant effect on bacteriocin production and proved to be a powerful tool in optimizing the culture conditions.

\section{References}

Biswas, S.R., Ray, P., Johnson, M.C., and Ray, B. 1991. Influence of growth conditions on the production of a bacteriocin, pediocin $\mathrm{AcH}$ by Pediococcus acidilactici. Journal of Applied Bacteriology. 57: 1265-1267.

Cladera-Olivera, F., Caron, G.R., and Brandelli, A. 2004. Bacteriocin-like substance production by Bacillus licheniformis strain P40.Letters in Applied Microbiology. 38(4):251-6.

De Vugst, L., and Vandamme, E.J. 1994. Bacteriocins of lactic acid bacteria. Microbiology, Genetics and 
Application. London: Blackie Acad and professional. ISBND- 75:140174-9.

Franz C.M.A.P., Schillinger, U., and Holzapfel, W.H. 1996. Production and characterization of enterocin 900, a bacteriocin produced by Enterococcus faecium BFE 900 from black olives. International Journal of Food Microbiology. 29: 255-270.

Ivanova, I., Kabadjova, P., Pantev, A., Danova, S., and Dousse, X. 2000. Detection, purification and characterization of a noval bacteriocin substance produced by Lactobacillus lactis subsp. lactis B14 isolated from boza-bulgarian traditional cereals beverage. Biocatalysis: Vestnik Maskovskogouniversitetakimia. 41(6): 47-53.

Joerger, M., and Klaenhammer, T.R. 1990. Cloning, expression, and nucleotide sequence of the Lactobacillus helveticus 481 gene encoding the bacteriocinhelveticin J. Journal of Bacteriology. 172: 6339-6347.

Kang, J.H., and Lee, M.S. 2005. Characterization of a bacteriocin produced by Enterococcus faecium GM-1 isolated from an infant. Journal of Applied Microbiology. 98: 11691176.

Keppler, K., Geisen, R., and Holzapfel, W.H. 1994. An $\alpha$-amylase sensitive bacteriocin of Leuconostoc carnosum. Food Microbiology. 11: 39-45.

Kumar, M., Jain, A.K., and Ghosh, M. 2012. Statistical Optimization of Physical Parameters for Enhanced Bacteriocin Production by L. casei. Biotechnology and Bioprocess Engineering. 17:606616.

Leães, F.L., Sant'Anna, V., and Vanin, N.G. 2011. Use of byproducts of food industry for production of antimicrobial activity by Bacillus sp. P11. Food Bioprocess Technology. 4:822-828.
Leal-Sánchez, M.V., Jiménez-Díaz, R., Maldonado-Barragán, A., GarridoFernández, A., and Ruiz-Barba, J.L. 2002. Optimization of bacteriocin production by batch fermentation of Lactobacillus plantarum LPCO10. Applied Environmental Microbiology. 68(9):4465-71.

Leroy, F., Lievens, K., and De Vuyst, L. 2005. Modeling, Bacteriocin Resistance and Inactivation of Listeria innocua LMG 13568 by Lactobacillus sakei CTC 494 under Sausage Fermentation Conditions. Applied Environmental Microbiology. 71(11): 7567-7570.

Mataragas, M., Metaxopoulos, J., Galiotou, M., and Drosinos, E.H. 2003. Influence of $\mathrm{pH}$ and temperature on growth and bacteriocin production by Leuconostoc mesenteroides L124 and Lactobacillus curvatus L442. Meat Science. 64:265271.

Montgomery, D.C. 1997. Design and Analysis of Experiments. 4th edition, John Wiley \& Sons, New York.

Oh, S., Rheem, S., Sim, J., Kim, S., and Back, Y. 1995. Optimizing conditions for the growth of Lactobacillus casei YIT 9018 in tryptone glucose medium by using response methodology. Applied and Environmental Microbiology. 61: 38093814.

Schved, F., Lalazar, A., Henis, Y., and Juven, B.J. 1993. Purification, partial characterization and plasmid- linkage of pediocin SJ-1, a bacteriocin produced by Pediococcus acidilactici. Journal of Applied Bacteriology. 74: 67-77.

Song, Y.L., Kato, N., Liu, C.X., Matsumiya, Y., Kato, H., and Watanabe, K. 2000. Rapid identification of 11 human intestinal Lactobacillus species by multiplex PCR assays using group- and species-specific primers derived from the $16 \mathrm{~S}-23 \mathrm{~S}$ rRNA intergenic spacer region and its flanking $23 \mathrm{~S}$ rRNA. 
FEMS Microbiology Letters. 187: 167173.

Todorov, S.D., and Dicks, L.M.T. 2004. Partial characterization of bacteriocin produced by four lactic acid bacteria isolated from regional South African barley beer. Annals of Microbiology. 54(4): 403-413.

Uhlman, U., Schillinger, U., Rupnow, J.R., and Holzapfel, W.H. 1992. Identification and characterization of two bacteriocin-producing strains of Lactococ cuslactis isolated from vegetables. International Journal of
Food Microbiology.16: 141-151.

Van-Laack, R.L.J.M., Schillinger, U., and Holzapfel, W. 1992. Characterization and partial purification of a bacteriocin produced by Leuconostoc carnosum LA44A. International Journal of Food Microbiology. 16: 183-195.

Zamhir M., Stefan, I.R., and Tudor, S.S.G. 2016. Influence of growth medium composition on the bacteriocin activity of some lactic acid bacteria. Romanian Biotechnological Letters. 22(6): 1212612135.

\section{How to cite this article:}

Neha Pandey and Ravinder Kumar Malik. 2019. Optimization of Bacteriocin Production from Lactobacillus gasseri NBL 18 through Response Surface Methodology. Int.J.Curr.Microbiol.App.Sci. 8(03): 2000-2008. doi: https://doi.org/10.20546/ijcmas.2019.803.238 